\title{
The Relationship Between Serum Asymmetric Dimethylarginine Levels and Cardiovascular Risk Factors in Children with Nephrotic Syndrome
}

\author{
Nefrotik Sendromlu Çocuklarda Serum Asimetrik Dimetilarjinin Düzeyleri ve \\ Kardiyovasküler Risk Faktörleri Arasındaki ilişki
}

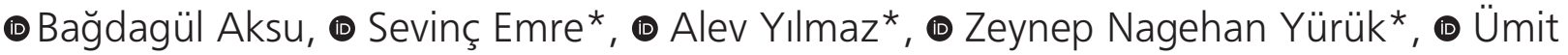 \\ Dilber Mutlu Demirel** , ๑ Oğuz Bülent Erol***, ๑ Cemile Pehlivanoğlu* \\ istanbul Haseki Training and Research Hospital, Clinic of Pediatric Nephrology, Istanbul, Turkey \\ *istanbul University Istanbul Faculty of Medicine, Department of Child Health and Diseases, Division of Pediatric Nephrology, \\ istanbul, Turkey \\ **istanbul University Istanbul Faculty of Medicine, Department of Biochemistry, Istanbul, Turkey \\ ***istanbul University istanbul Faculty of Medicine, Department of Child Health and Diseases, Division of Pediatric Radiology, istanbul, \\ Turkey
}

\section{Abstract}

\begin{abstract}
Aim: Nephrotic syndrome is a common type of kidney disease during childhood characterized by proteinuria, edema and hypoalbuminemia. Serum asymmetric dimethylarginine (ADMA) inhibits vascular nitric oxide production and may be an independent risk factor for coronary heart disease. The aim of this study was to investigate the relationship between ADMA and atherosclerotic risk factors in children with nephrotic syndrome.
\end{abstract}

Methods: Forty-one children with nephrotic syndrome and 33 healthy children were included in the study. Patients' demographic and anthropometric characteristics, biochemical tests, serum homocysteine, ADMA and carotid intima-media thickness (CIMT) were assessed. The patients were divided into three groups: group 1 - steroid-free remission; group 2 - steroid-induced remission, still on steroid therapy; and group 3 - active proteinuria.

Results: The patient and control groups were similar in terms of age, sex, weight, height, body mass index, and systolic blood pressure ( $p>0.05)$. Diastolic blood pressure was significantly higher in children with nephrosis than in controls. Serum ADMA, homocysteine and CIMT measurements were not different between the two groups $(p>0.05)$. There was a positive correlation between diastolic blood pressure and CIMT measurement in patients. In group 3, ADMA was
Öz

Amaç: Nefrotik sendrom, çocukluk yaş grubunun sık görülen böbrek hastalıklarından biri olup ödem, masif proteinüri, hipoalbüminemi ve hiperlipidemi ile karakterizedir. Serum asimetrik dimetilarjinin (ADMA), vasküler nitrik oksit üretimini inhibe eder ve koroner kalp hastalığı için bağımsız bir risk faktörü olabilir. Bu çalışmanın amacı, nefrotik çocuklarda ADMA ve aterosklerotik risk faktörleri arasındaki ilişkiyi değerlendirmektir.

Yöntemler: Çalışmaya nefrotik sendromlu 41 hasta ve 33 sağlıklı çocuk dahil edildi. Hastaların demografik ve antropometrik özellikleri, biyokimyasal testleri, serum homosistein, serum ADMA ve karotis intima-media kalınlığı (KiMK) değerlendirildi. Nefrotik sendromlu hastalar, steroid tedavisi ile remisyona girmiş, tedavisi kesilmiş olanlar $(n=18)$, steroid tedavisi ile remisyona girmiş, tedavisi devam edenler $(n=11)$ ve aktif proteinürisi olanlar ( $n=12)$ olmak üzere üç gruba ayrıldı.

Bulgular: Nefrotik sendromlu hastalar ve kontrol grubu, cinsiyet, yaş, vücut ağılığı, boy, vücut kitle indeksi ve sistolik kan basıncı açısından benzerdi $(p>0,05)$. Nefrotik çocuklarda, diyastolik kan basıncı kontrol grubundan anlamlı yüksekti. Serum ADMA, serum homosistein seviyeleri ve KiMK ölçümü açısından iki grup arasında fark yoktu $(p>0,05)$. Nefrotik sendromlu hastalarda KiMK ölçümü ile diyastolik kan basıncı arasında pozitif bir ilişki saptandı. Grup 3'te serum ADMA
Address for Correspondence/Yazışma Adresi: Bağdagül Aksu

Istanbul Haseki Training and Research Hospital, Clinic of Pediatric Nephrology, İstanbul, Turkey E-mail: bagdagul@yahoo.com ORCID ID: orcid.org/000-0003-3274-8024

Received/Geliş Tarihi: 16 April 2018 Accepted/Kabul Tarihi: 24 July 2018
${ }^{\circ}$ Copyright 2019 by The Medical Bulletin of istanbul Haseki Training and Research Hospital The Medical Bulletin of Haseki published by Galenos Yayınevi. ${ }^{\circledR}$ Telif Hakkı 2019 İstanbul Haseki Eğitim ve Araştırma Hastanesi Haseki Tip Bülteni, Galenos Yayınevi tarafından yayınlanmıştır. 
positively correlated with total cholesterol and low density lipoprotein cholesterol.

Conclusion: Children with idiopathic nephrotic syndrome did not show signs of endothelial damage assessed by ADMA and CIMT.

Keywords: Nephrotic syndrome, children, atherosclerosis, asymmetric dimethylarginine, carotid intima-media thickness düzeyleri ile total kolesterol ve düşük yoğunluklu lipoprotein-kolesterol arasında pozitif bir ilişki gösterildi.

Sonuç: idiyopatik nefrotik sendromlu çocuklarda serum ADMA ve KiMK ile değerlendirilen endotelyal hasar bulguları gözlenmedi.

Anahtar Sözcükler: Nefrotik sendrom, çocuk, ateroskleroz, asimetrik dimetilarji, karotis intima media kalınlığı

\section{Introduction}

Idiopathic nephrotic syndrome (INS) is a common renal disease during childhood characterized by proteinuria, edema and hypoalbuminemia (1). Prolonged duration of nephrotic status results in increased risk for cardiovascular disease due to the risk factors including hyperlipidemia, hypertension, using corticosteroids and immunosuppressive drugs, hypercoagulability, and oxidative stress (2). INS is considered an important risk factor for accelerated atherosclerosis in the adult population. However, the role of nephrotic syndrome in the development of atherosclerosis in children is not clear (3).

Endothelial dysfunction is an early pathophysiological feature and an independent predictor of poor prognosis in many forms of cardiovascular disease. The integrity of the endothelial function is highly dependent on normal nitric oxide (NO) production (4). Asymmetric dimethylarginine (ADMA), an endogenous inhibitor of NO synthase (NOS), inhibits vascular NO production. $\mathrm{NO}$ is responsible for various regulatory mechanisms in the cardiovascular system and defined as an antiatherogenic molecule $(3,4)$. Recent studies have shown that increased levels of serum ADMA was an independent risk factor for coronary heart disease (5). Serum ADMA levels increase in atherosclerotic disease and in conditions that are risk factors for coronary heart disease such as hypercholesterolemia, hypertriglyceridemia, hypertension, insulin resistance, diabetes, and hyperhomocysteinemia $(6,7)$.

Carotid intima-media thickness (CIMT) measurement with B-mode ultrasound is a noninvasive, reliable, and relatively inexpensive method for detection of subclinical atherosclerosis (8). Epidemiologic studies have demonstrated the relationship of ADMA and CIMT with atherosclerosis (9-11).

The aim of this study was to investigate the relationship of ADMA with CIMT, an indicator of subclinical atherosclerosis, and atherosclerotic risk factors in children with INS.

\section{Methods}

This study was approved by the ethical committee of the istanbul Medical Faculty (2013/706), in accordance with the Declaration of Helsinki. Informed consent was obtained from the parents of the patients and the controls. The study group comprised 41 children ( 25 boys, 16 girls) with INS who were under follow-up in our outpatient clinic.

INS was diagnosed in all patients in accordance with the criteria recommended by the International Study for Kidney Diseases in Children (12). Fifteen patients underwent kidney biopsy. The diagnosis was focal segmental glomerulosclerosis (FSGS) in five patients and minimal change disease in the remaining 10 patients.

The children were divided into three subgroups:

Group 1: Steroid-free remission $(n=18)$;

Group 2: Steroid-induced remission, still on steroid therapy $(n=11)$;

Group 3: Active proteinuria despite steroid and/or other immunosuppressive therapy $(n=12)$.

In group 3, five patients were being treated with cyclosporine $(n=4)$ or mycophenolate mofetil $(n=1)$ for FSGS, the remaining seven patients were at the beginning of a new attack and still had active proteinuria although steroid had been initiated.

The control group consisted of 33 age- and sexmatched healthy subjects (17 boys and 16 girls) with no history of INS and/or proteinuria.

CIMT measurement with B-mode ultrasound was performed for the detection of subclinical atherosclerosis in the patient and control groups. Body mass index (BMI), systolic and diastolic blood pressure (BP), serum lipid profile, and serum homocysteine levels were assessed as risk factors for atherosclerosis.

\section{Anthropometric Measurements}

Weight $(\mathrm{kg})$ and height $(\mathrm{cm})$ of the subjects were measured by the same nurse. BMI was calculated as weight $/$ height $^{2}\left(\mathrm{~kg} / \mathrm{m}^{2}\right)$; the standard deviation scores (SDS) of BMI was also computed via the LMS method using BMI references for Turkish children. Patients with a BMI SDS >2 were defined as obese and those with a BMI SDS 1-2, overweight (13).

BP was measured using an average of 3 consecutive BP measurements with standard sphygmomanometer. Physical activity was avoided for at least 10 min before BP measurement. The tables of the task force report on high $\mathrm{BP}$ in children and adolescents were used to evaluate BP (14). 


\section{Ultrasound CIMT Measurements}

Measurements were performed using a $12 \mathrm{Mhz}$ probe and still image settings on the same device (Logiq 9 GE Healthcare, Milwaukee, WI, USA) by the same operator. The carotid arteries were scanned longitudinally with the patient lying in the supine position. The IMT of the right and left common carotid artery, bifurcation, and the first $2 \mathrm{~cm}$ of the internal carotid artery were measured from three different points, evaluating only the posterior wall. Three measurements were made in each patient, and the mean value was calculated (15).

\section{Laboratory Measurements}

Blood samples were drawn in the morning after an overnight fast (at least $12 \mathrm{~h}$ ). Serum was immediately separated from blood cells using centrifugation at 3000 rpm for 5 min and stored at $-20^{\circ} \mathrm{C}$ until required for analysis. Serum ADMA level was measured using an enzyme-linked immunosorbent assay (MASSAY bio-medical assay, China).

Serum total cholesterol, high-density lipoprotein (HDL) cholesterol, triglycerides, and homocysteine were assayed on a modular autoanalyzer (Roche). Serum lowdensity lipoprotein (LDL) cholesterol was calculated using Friedewald's formula (16). Dyslipidemia was defined as a total cholesterol level of $\geq 200 \mathrm{mg} / \mathrm{dL}$, triglycerides $\geq 150$ $\mathrm{mg} / \mathrm{dL}$, and $\mathrm{LDL}$ cholesterol $\geq 130 \mathrm{mg} / \mathrm{dL}$ (17). Normal serum levels of homocysteine in childhood are considered 3.3-11.3 $\mu \mathrm{mol} / \mathrm{L}$ (18). For all patients, urinalysis was evaluated, and in patients with active proteinuria, the spot urine protein/creatinine ratio was calculated. Proteinuria was defined as a urine protein/creatinine ratio of $>0.2$ $\mathrm{mg} / \mathrm{mgCr}$ and nephrotic range proteinuria was defined as a urine protein/creatinine ratio of $>2 \mathrm{mg} / \mathrm{mgCr}$.

\section{Statistical Analysis}

Analyses were performed using SPSS v. 21.0 package program for Windows. The results are expressed as mean \pm SD and median (lower and upper limit) for descriptive data. The normality of the parameters was tested using the Shapiro-Wilk test.

Parametric (Student's t-test) and nonparametric tests (Mann-Whitney $U$ test or Kruskal-Wallis test in cases of more than 2 groups) were used for betweengroup comparisons. Relationships between variables were analyzed using correlation (Pearson's correlation coefficient and Spearman's coefficient). A $p$ value of less than 0.05 was considered statistically significant.

\section{Results}

\section{Clinical Characteristics}

The mean age of the patients and control group was $9.2 \pm 4.2$ years (range, 3.5-17.8 years) and 10.3 \pm 3.2 years (range, 3-15.8 years), respectively. The two groups were similar for age and sex ( $p>0.05)$ (Table 1). Moreover, comparing the subgroups with each other, there was no significant difference for age and sex ( $p>0.05$ ) (Table 2).

The mean age of INS onset was 5.0 \pm 3.1 years (1.5-14.5 years) and the mean follow-up duration was $49.0 \pm 42.5$ months (1-192 months). The mean duration of remission was 5.6 \pm 12.0 months (0-50 months) in group 1 and 2 . The mean number of relapses of patients, except FSGS, was $3.9 \pm 3.2$ during follow-up. In five patients with FSGS, the number of relapses could not be calculated, because they were not in remission despite use of immunosuppressive drugs. In the patients with active proteinuria (group 3), the mean protein/creatinine ratio in spot urine was $4.0 \pm 4.4$ $\mathrm{mg} / \mathrm{mgcr}$.

\section{Risk Factors for Atherosclerosis}

The patient and control groups were similar in terms of BMI, and systolic BP $(p>0.05)$. The patients had significantly higher diastolic BP compared with healthy controls $(p=0.018)$ (Table 1). The median diastolic BP was significantly higher in group 3 than in the controls $(p=0.032)$, whereas group 3 and control group were not different for BMI and systolic BP ( $p>0.05)$. Groups 1 and 2 were compared with the control group in regards to BMI, and systolic and diastolic BP (Table 2).

Serum total cholesterol and triglycerides were significantly higher in the patients than in the controls ( $p=0.019$ and $p=0.004$, respectively), although serum LDL and HDL cholesterol did not differ between the groups (Table 1). Also, in group 3, serum total cholesterol, LDL and $\mathrm{HDL}$ cholesterol, and triglycerides were significantly higher than in the controls $(p<0.05)$. There was no difference in serum lipid profile between groups 1 and 2 and the controls (Table 2).

Serum homocysteine levels were not different between patient and control groups (Table 1), or between subgroups and control groups (Table 2).

\section{Serum ADMA Levels and CIMT Measurements and Risk Factors for Atherosclerosis}

When we compared the groups with each other, serum ADMA levels and CIMT were not significantly different between the patient and control groups (Table 1), or among the subgroups (Table 2). In addition, there was no correlation between serum levels of ADMA and CIMT measurements in Spearman's test. CIMT measurement was positively correlated with diastolic BP in the patient group ( $r=0.332 ; p=0.034)$.

Serum levels of ADMA were not related with age, sex, $B M I, B P$, serum profile and homocysteine the patient group ( $p>0.05)$. Among the patients in group 3, serum ADMA levels were significantly higher in patients whose serum total cholesterol levels were $>200 \mathrm{mg} / \mathrm{dL}(0.122 \mu \mathrm{mol} / \mathrm{L}$ 
vs $0.038 \mu \mathrm{mol} / \mathrm{L} ; \mathrm{p}=0.042$ ) and a positive correlation was detected between serum levels of ADMA and total (Figure 1) and LDL cholesterol (Figure 2).

\section{Discussion}

Endothelial dysfunction and increased IMT are the most important changes in early-stage subclinical atherosclerotic disease. ADMA, an endogenous inhibitor of NOS, was found to be correlated with endothelial dysfunction and proteinuria in patients with chronic renal disease $(19,20)$.
Vallance et al. (21) showed that endothelial function was impaired by exogenous ADMA administration. Moreover, it has been shown that endothelial dysfunction in chronic renal failure was improved by removing ADMA with hemodialysis (22). Few studies have associated ADMA with INS. Although serum ADMA levels in Schimkeimmuno-osseous dysplasia were not different from those of the controls (23), Lücke et al. (24) found significantly higher ADMA levels in patients with sporadic FSGS, and suggested that ADMA might have a role in the

\begin{tabular}{|c|c|c|c|}
\hline & $\begin{array}{l}\text { Patients } \\
(n=41)\end{array}$ & $\begin{array}{l}\text { Controls } \\
(n=33)\end{array}$ & $p$ \\
\hline $\begin{array}{l}\text { Clinical parameters } \\
\text { Age, years }\end{array}$ & 8 & 10 & 0.146 \\
\hline Sex, male/female (n) & $25 / 16$ & $17 / 16$ & 0.414 \\
\hline $\mathrm{BMI}, \mathrm{kg} / \mathrm{m}^{2}$ & 18.8 & 17.8 & 0.294 \\
\hline Systolic BP, mmHg & 106 & 106 & 0.331 \\
\hline Diastolic BP, mmHg & $65.4 \pm 6.5$ & $61.6 \pm 7.0$ & 0.018 \\
\hline $\begin{array}{l}\text { Laboratory parameters } \\
\text { Total cholesterol, mg/dL }\end{array}$ & 158 & 143 & 0.019 \\
\hline LDL-cholesterol, mg/dL & 90.0 & 75.4 & 0.062 \\
\hline HDL-cholesterol, mg/dL & 54.0 & 50.0 & 0.333 \\
\hline Triglycerides, mg/dL & 90.0 & 64.0 & 0.004 \\
\hline Homocysteine, $\mu \mathrm{mol} / \mathrm{L}$ & 7.8 & 9.8 & 0.052 \\
\hline ADMA, $\mu \mathrm{mol} / \mathrm{L}$ & 0.122 & 0.159 & 0.358 \\
\hline CIMT, mm & 0.45 & 0.50 & 0.698 \\
\hline \multicolumn{4}{|c|}{$\begin{array}{l}\text { LDL: Low-density lipoprotein, HDL: High-density lipoprotein, ADMA: Asymmetric dimethylarginine, CIMT: Carotid intima-media thickness, BMI: Body mass index, BP: Blood } \\
\text { pressure } \\
\text { Data are presented as median or mean } \pm \text { standard deviation }\end{array}$} \\
\hline
\end{tabular}

\section{Table 2. Clinical and laboratory characteristics of the subgroups and controls}

\begin{tabular}{|c|c|c|c|c|c|}
\hline & $\begin{array}{l}\text { Group } 1 \\
(n=18)\end{array}$ & $\begin{array}{l}\text { Group } 2 \\
(n=11)\end{array}$ & $\begin{array}{l}\text { Group } 3 \\
(n=12)\end{array}$ & $\begin{array}{l}\text { Control } \\
(n=33)\end{array}$ & $p$ \\
\hline $\begin{array}{l}\text { Clinical parameters } \\
\text { Age, years }\end{array}$ & 8 & 6 & 11 & 10 & 0.295 \\
\hline Sex, male/female (n) & $12 / 6$ & $3 / 8$ & $7 / 5$ & $17 / 16$ & 0.341 \\
\hline $\mathrm{BMI}, \mathrm{kg} / \mathrm{m}^{2}$ & 19.5 & 15.8 & 18.5 & 17.8 & 0.318 \\
\hline Systolic BP, mmHg & 105 & 106 & 113 & 106 & 0.456 \\
\hline Diastolic BP, mmHg & 64 & 61 & 70 & 63 & 0.046 \\
\hline $\begin{array}{l}\text { Laboratory parameters } \\
\text { Total cholesterol, mg/dL }\end{array}$ & 153 & 146 & 217 & 143 & 0.001 \\
\hline LDL-cholesterol, mg/dL & 85.7 & 72.0 & 129.9 & 75.4 & 0.004 \\
\hline HDL-cholesterol, mg/dL & 47 & 58 & 69 & 50.0 & 0.013 \\
\hline Triglycerides, mg/dL & 85 & 76 & 106 & 64.0 & 0.016 \\
\hline Homocysteine, $\mu \mathrm{mol} / \mathrm{L}$ & 7.6 & 7.4 & 8.5 & 9.8 & 0.205 \\
\hline ADMA, $\mu \mathrm{mol} / \mathrm{L}$ & 0.151 & 0.113 & 0.103 & 0.159 & 0.280 \\
\hline CIMT, mm & 0.50 & 0.45 & 0.48 & 0.50 & 0.941 \\
\hline
\end{tabular}

LDL: Low-density lipoprotein, HDL: High-density lipoprotein, ADMA: Asymmetric dimethylarginine, CIMT: Carotid intima-media thickness, BMI: Body mass index, BP: Blood pressure

Data are presented as median 
pathophysiology of a subgroup of INS. Hyla-Klekot et al. (25) showed that serum ADMA levels were not different in remission from the active phase of INS.

Our study was designed to investigate a possible relationship of ADMA with CIMT, an indicator of atherosclerosis, and the risk factors for atherosclerosis such as BMI, dyslipidemia, BP, and homocysteine in children with INS.

According to our results, there was no difference in serum levels of ADMA between the patients and controls,

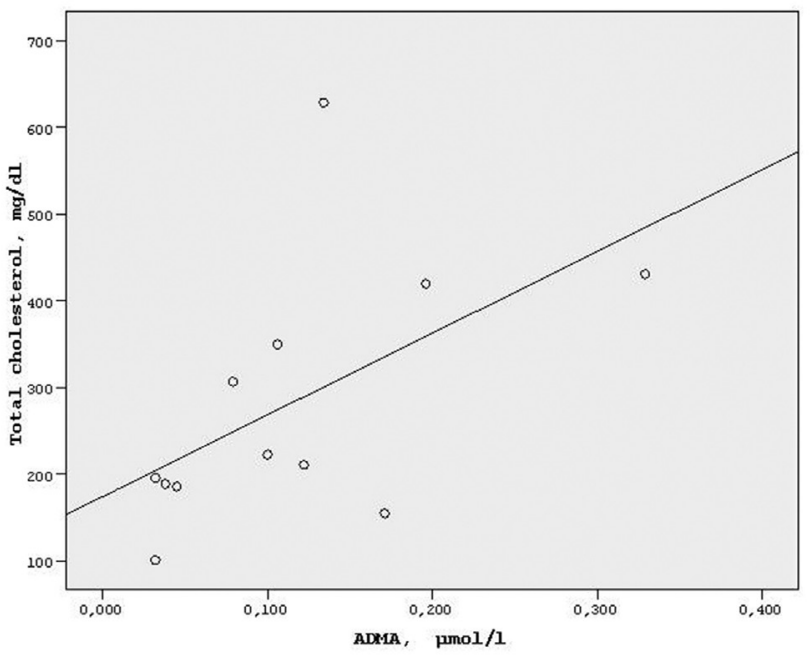

Figure 1. Correlation between plasma ADMA concentration and total cholesterol in group 3 (active proteinuric group). Spearman's correlation coefficient $r=0.623 ; p=0.030$ ADMA: Asymmetric dimethylarginine

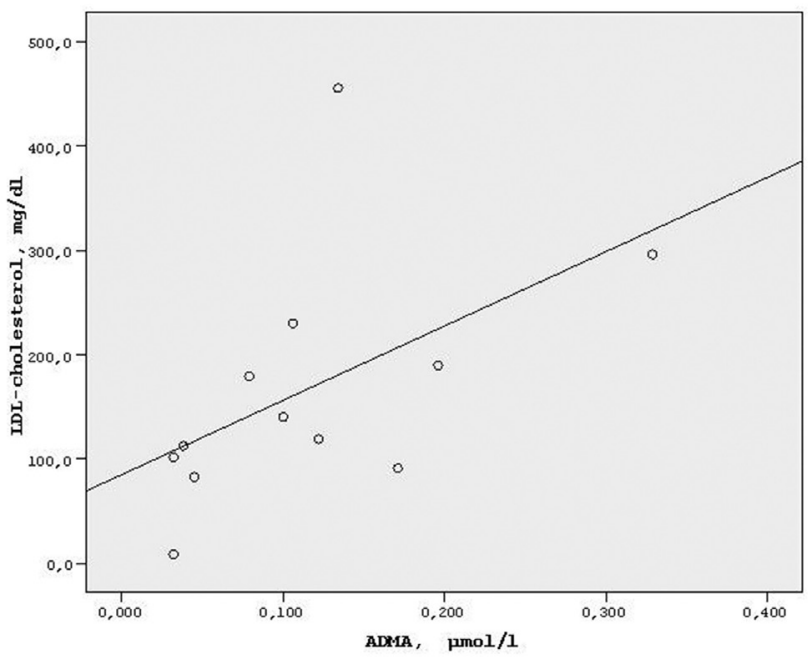

Figure 2. Correlation between plasma ADMA concentration and LDL cholesterol in group 3 (active proteinuric group). Spearman's correlation coefficient $r=0.648 ; p=0.023$

ADMA: Asymmetric dimethylarginine as well as in the INS subgroups. The reason why serum ADMA levels were not elevated in INS may be that CIMT was also normal, which suggests that there was no remarkable atherosclerosis in our study group.

In some of the studies evaluating CIMT in children with INS, CIMT was found to be higher compared with controls, whereas other studies reported that there was no difference. CIMT has been reported to be increased in majority of children who were currently being treated for steroid-resistant NS (SRNS) and steroid-dependent NS (SDNS) (26-28). The majority of our patients had steroid-sensitive NS (SSNS) and they were in remission, as with another study that found normal IMT (29-31). Moreover, the mean follow-up duration of our patients was shorter than in studies that reported increased CIMT in INS (49 months vs. 93.7-94.5 months), which suggests that longer duration of nephrotic condition may be needed for emergence of atherosclerosis. In addition, the number of relapses was small as once or twice during follow-up in nearly half of our children. It may be expected that CIMT, and therefore ADMA, were not high in our patients because of the transient nature of metabolic changes and steroid exposure in SSNS.

When we evaluated the relationship between ADMA and risk factors for atherosclerosis, there was no difference between patients with INS and the control group in terms of $\mathrm{BMI}$, systolic BP, and homocysteine, and there was no relationship between serum ADMA levels and these factors. Diastolic BP, total cholesterol, LDL cholesterol, and triglyceride levels were higher in patients with INS compared with the controls. This difference appears to be caused by the patients with active proteinuria (group 3). The presence of dyslipidemia is expected in the acute phase of INS. In addition, serum ADMA levels were significantly higher in patients whose serum total cholesterol levels were $>200 \mathrm{mg} / \mathrm{dL}$, and serum ADMA levels were positively correlated with total cholesterol, and LDL cholesterol in this group. It has been demonstrated that plasma concentration of ADMA was elevated due to hypercholesterolemia (32). Moreover Kitova et al. (33) reported that plasma level of ADMA was found to be increased in patients with non-treated asymptomatic hypercholesterolemia. However, diastolic BP was not correlated with serum ADMA levels, although it was found to be correlated with CIMT.

It has been reported that there was no increased risk for cardiovascular disease in young adults with relapsing childhood SSNS (3). Supporting this study, our findings suggest that serum ADMA levels are not a useful marker to indicate endothelial dysfunction in children with INS. These results should be interpreted while considering that 
the majority of our patients was steroid-sensitive and in remission at the time of study.

Regression of proteinuria, recovery of the lipid metabolism, and cessation of steroid therapy may result in the elimination of risk factors and remission of early atherosclerotic changes in SSNS. Dyslipidemia and BP should be closely monitored in patients with SDNS and SRNS.

\section{Conclusion}

In conclusion, children with INS did not show signs of endothelial damage assessed by ADMA and CIMT. This may be due to short duration of the nephrotic state. A long-term follow-up of children with INS is needed to determine atherosclerosis.

\section{Authorship Contributions}

Surgical and Medical Practices: B.A. Concept: B.A. Design: B.A., S.E. Data Collection or Processing: B.A., Z.N.Y., C.P. Analysis or Interpretation: B.A., Ü.D.M.D., O.B.E. Literature Search: B.A. Writing: B.A., A. Y.

Conflict of Interest: The authors declared that they have no conflict of interest.

Financial Disclosure: This study was supported by Istanbul University Scientific Research Project Foundation grant number of 35351 dated 2014.

\section{References}

1. Valentini RP, Smoyer WE. Nephrotic syndrome. In: Kher KK, Schnaper HW, Makker SP, editors. Clinical Pediatric Nephrology. 2nd ed. London; 2006: pp. 155-94.

2. Eddy AA, Symsons JM. Nephrotic syndrome in childhood. Lancet 2003;23:629-39.

3. Lechner BL, Bockenauer D, Iragorri S, Kennedy TL, Siegel NJ. The risk of cardiovascular disease in adults who have had childhood nephrotic syndrome. Pediatr Nephrol 2004;19:7448.

4. Cai H, Harrison DG. Endothelial dysfunction in cardiovascular diseases: the role of oxidant stress. Circ Res 2000;87:840-4.

5. Schulze $F$, Lenzen $H$, Hanefeld $C$, et al. Asymmetric dimethylarginine is an independent risk factor for coronary heart disease: results from the multicenter Coronary Artery Risk Determination investigating the Influence of ADMA Concentration (CARDIAC) study. Am Heart J 2006;152:493. e1-8.

6. Vallance P, Leiper J. Cardiovascular biology of asymmetric dimetylarginine: dimethylarginine dimethylaminohydrolase pathway. Arterioscler Thromb Vasc Biol 2004;24:1023-30.

7. Böger $\mathrm{RH}$. The emerging role of asymmetric dimethylarginine as a novel cardiovascular risk factor. Cardiovasc Res 2003;59:824-33.

8. Pearson J, Formgren J, Israelsson B, Berglund G. Ultrasound determined intima-media thickness: direct and indirect validation. Atheroscl Thromb 1994;14:261-4.

9. Furuki $K$, Adachi $H$, Matsuoka $H$, et al. Plasma levels of asymmetric dimethylarginine (ADMA) are related to intimamedia thickness of the carotid artery: an epidemiological study. Atherosclerosis 2007;191:206-10.

10. Furuki $K$, Adachi $H$, Enomoto $M$, et al. Plasma level of asymmetric dimethylarginine (ADMA) as a predictor of carotid intima-media thickness progression: six-year prospective study using carotid ultrasonography. Hypertens Res 2008;31:11859.

11. 11-Bai $Y$, Sun $L$, Du L, et al. Association of circulating levels of asymmetric dimethylarginine (ADMA) with carotid intimamedia thickness: evidence from 6168 participants. Ageing Res Rev 2013;12:699-707.

12. The primary nephrotic syndrome in children. Identification of patients with minimal change nephrotic syndrome from initial response to prednisone. A report of the International Study of Kidney Disease in Children. J Pediatr 1981;98:561-4.

13. Bundak R, Furman A, Günöz $H$, Darendeliler F, Baş $F$, Neyzi O. Body mass index references for Turkish children, Acta Paediatr 2006;95:194-8.

14. The fourth report on the diagnosis, evaluation, and treatment of high blood pressure in children and adolescents. National High Blood Pressure Education Program Working Group on High Blood Pressure in Children and Adolescents. Pediatrics 2004;114:555-76.

15. Homma S, Hirose N, Ishida H, Ishii T, Araki G. Carotid plaque and intima-media thickness assessed by B-mode ultrasonography in subjects ranging from young adults to centenarians. Stroke 2001;32:830-5.

16. Friedewald WT, Levy RI, Fredrickson DS. Estimation of the concentration of low density lipoprotein cholesterol in plasma without use of preparative ultracentrifuge. Clin Biochem 1972;18:494-502.

17. Third Report of the National Cholesterol Education Program Expert Panel on Detection, Evaluation and Treatment of High Blood Cholesterol in Adults (Adult Treatment Panel III). Bethesda, MD: National Heart, Lung, and Blood Institute 2001.

18. Nicholson JF, Pesce MA. Reference ranges for labaratory tests and procedures. In: Behrman RE, Kliegman RM, Jenson HB (eds): Nelson Textbook of Pediatrics. 17. edition, Philadelphia, USA, Saunders, 2004:2396-427.

19. Caglar K, Yilmaz MI, Sonmez A, et al. ADMA, proteinuria, and insulin resistance in non-diabetic stage I chronic kidney disease. Kidney Int 2006;70:781-7.

20. Yilmaz MI, Sonmez A, Saglam M, et al. ADMA levels correlate with proteinuria, secondary amyloidosis, and endothelial dysfunction. J Am Soc Nephrol 2008; 19:388-95.

21. Vallance $P$, Leone $A$, Calver A, Collier J, Moncada S. Endogenous dimethylarginine as an inhibitor of nitric oxide synthesis. J Cardiovasc Pharmacol 1992;20:60-2.

22. Cross JM, Donald AE, Kharbanda R, Deanfield JE, Woolfson RG, Mac Allister RJ. Acute administration of L-arginine does 
not improve arterial endothelial function in chronic renal failure. Kidney Int. Dec 2001;60:2318-23.

23. Lücke T, Tsikas $D$, Kanzelmeyer NK, et al. Vaso-occlusion in Schimke-immuno-osseous dysplasia: is the NO pathway involved? Horm Metab Res 2006;38:678-82.

24. Lücke T, Kanzelmeyer N, Chobanyan K, et al. Elevated asymmetric dimethylarginine (ADMA) and inverse correlation between circulating ADMA and glomerular filtration rate in children with sporadic focal segmental glomerulosclerosis (FSGS). Nephrol Dial Transplant 2008;23:734-40.

25. Hyla-Klekot L, Bryniarski P, Pulcer B, Ziora K, Paradysz A. Dimethylarginines as risk markers of atherosclerosis and chronic kidney disease in children with nephrotic syndrome. Adv Clin Exp Med 2015;24:307-14.

26. Candan C, Canpolat N, Gökalp S, et al. Subclinical cardiovascular disease and its association with risk factors in children with steroid-resistant nephrotic syndrome. Pediatr Nephrol 2014;29:95-102.

27. Ksiazek J, Niemirska A, Lipka M, Grenda R. Evaluation of arterial intima-media thickness (IMT) in children with idiopathic nephrotic syndrome - preliminary report. Przegl Lek 2006;63:205-207.
28. Hooman N, Isa-Tafreshi R, Otukesh H, Mostafavi SH, Hallaji F. Carotid Artery Function in Children with Idiopathic Nephrotic Syndrome Nefrologia 2013;33:650-6.

29. Kniazewska MH, Obuchowicz AK, Wielkoszy ski T, et al. Atherosclerosis risk factors in young patients formerly treated for idiopathic nephrotic syndrome. Pediatr Nephrol 2009;24:549-54.

30. Hooman N, Mostafavi SH, Hallaji F, Isa-Tafreshi R, Otukesh $\mathrm{H}$. The correlation between atherosclerosis risk factors and carotid intima media thickness in children with nephrotic syndrome. Pediatr Nephrol 2010;25:1957.

31. Rahul I, Krishnamurthy S, Satheesh S, Biswal N, Bobby Z, Lakshminarayanan S. Brachial artery flow-mediated dilatation and carotid intima medial thickness in pediatric nephrotic syndrome: a cross-sectional case-control study.Clin Exp Nephrol 2015;19:125-32.

32. Böger RH, Sydow K, Borlak J, et al. LDL Cholesterol upregulates synthesis of asymmetrical dimethylarginine in human endothelial cells involvement of s-adenosylmethioninedependent methyltransferases. Circ Res 2000;87:99-105.

33. Kitova LV, Terzieva D, Nikolov F, Mateva N. Asymmetric dimethylarginine in hyper-cholesterolemic patients. Journal of IMAB - Annual Proceeding (Scientific Papers) 2007;13:110-2. 